\title{
Water quality in an urbanized river basin impacted by multi-pollution sources: From comprehensive surveys to modelling
}

\author{
Minh T.N. Luu ${ }^{\mathrm{a}}$, Truong D. Dinh ${ }^{\mathrm{b}}$, Duc A. Trinh ${ }^{\mathrm{c}}$, Nga T. Do ${ }^{\mathrm{c}, \mathrm{d}, *}$ \\ ${ }^{a}$ Institute of Chemistry, Vietnam Academy of Sciences and Technology, Hanoi 100000 Vietnam \\ b Faculty of Environment, Climate Change and Urban studies, National Economics University, Hanoi \\ 100000 Vietnam \\ ${ }^{c}$ Nuclear Training Center, Vietnam Atomic Energy Institute, Hanoi 100000 Vietnam \\ d Electric Power University, Hanoi 100000 Vietnam
}

*Corresponding author, e-mail: dothu_nga2005@yahoo.com

\begin{abstract}
The Seneque/Riverstrahler (SR) model, which was developed to establish links between the biogeochemical functioning of river systems and the constraints set by their (i) meteorology, (ii) drainage network morphology and (iii) human activities, was applied to the Day-Nhue River basin (DNRB). The DNRB is the most polluted area in northern part of Vietnam where domestic, industrial, agricultural and aquacultural activities have generated multiple sources of pollutants to the DNRB. Questionnaire surveys were conducted in industrial zones (at manufacturers and factories) of the DNRB to establish initial conditions of industrial activities for the SR. At the same time, water samples were collected from various industrial sectors and analyzed for suspended matter and nutrients. Additionally, river water quality surveys were conducted monthly at 11 stations inside the DNRB in 2006 and 2015. Simulation results from the SR model were then compared with analytical results of water quality for model validation. As a result, a nutrient budget of the river network was established to access the risk of coastal eutrophication in the Tonkin Bay. The model will provide adequate knowledge for policy makers to develop suitable water pollution management plans regarding nutrient sources and sinks.
\end{abstract}

KEYWORDS: coastal eutrophication, Seneque/Riverstrahler model, tropical river, Day-Nhue River basin

\section{INTRODUCTION}

Rivers are among the most diverse and threatened ecosystems on earth, and the preservation of good river water quality is a requisite for sustainable development. Conservation must consider both the structure and the functioning of biogeochemical cycling in these systems and their ecosystems as a whole. River ecosystems provide essential benefits and services to society, including water purification, transport and transformation of organic matter and other materials, nutrient cycling, flood control and so on $[1,2]$. Indeed, river deltas are known for their role in filtering of pollutants and protection of coastal areas from anthropogenic impacts $[2,3]$. In China, a study on pollution caused by polycyclic aromatic hydrocarbons in the surface soil of Guan River Estuary Industrial area has been reported [4]. Knowledge of the transfer and conversion of nutrients (nitrogen, phosphorus and silica) in river system is essential to understand the function of aquatic ecosystems [5]. The nutrient loading of rivers depends on both the natural geomorphic characteristics of the basin and the anthropogenic activities that occur within the catchment. Models can help to assess the relative significance of the complex and interacting processes driven by landuse and human activity in a given river basin and the impacts on river water quality and ecological functioning [1].

While several models such as Hydrological Simulation Program-FORTRAN (HSPF) [6], the Integrated Catchment Model-Nitrogen (INCA-N) model [7] and HBV-NP model [8] have been developed to focus on nutrient load estimations in river basins, the Seneque/Riverstrahler (SR) model has been established with the aim to understand the role of natural and anthropogenic factors impacting on the biogeochemical functioning of a river system. In addition to that, the SR model shows a great flex- 
ibility because it is open source and capable of describing the biogeochemical functioning of an entire river system, ranging between 100 to $>100000 \mathrm{~km}^{2}$ while the core system structure of other models is hard to be adapted for specific site conditions. The SR model takes into account the constraints set by the morphology of the drainage network, the meteorological/hydrological conditions and the inputs of materials from point and non-point sources in the river basin. This establishes the link between nutrient loading and hydrological conditions of the river system. The SR model has been validated on basins in temperate climate zones such as the Seine, Somme and Scheldt [9] and also in tropical basins such as the Red River in Vietnam $[10,11]$ and the Nam Khan River in Laos [12]. In these studies, the model simulates the spatio-temporal variation of 22 parameters characterizing the water quality and ecological functioning, including suspended matters, dissolved oxygen, nutrients (nitrate, ammonium, dissolved phosphate, particulate inorganic phosphorus and dissolved silica), 3 taxonomic groups of phytoplankton, 2 types of zooplankton and 4 compartments of bacteria. The model also includes nutrient budget calculations of the river basin as a result of a combination of hydrological and ecological models. Indeed, the SR model has been successfully applied to the upstream Red River Basin which belongs to China $[10,11]$. The extension of the model to the downstream of the basin, where Red River Delta is located, represents a step further for a land-to-sea view of the hydrosystem.

Budgets of water and nutrient transfer established at the scale of the Red River Delta $\left(14300 \mathrm{~km}^{2}\right)$ show that more than half of the total amount of nitrogen and phosphorus brought from the upstream catchment and from regional human activities is eliminated or retained before reaching the sea $[13,14]$. Sedimentation plays a major role in phosphorus retention while both waterlogged delta soils and the poorly oxygenated water of a large part of the drainage network contribute to storing the total nutrient load. The delta, therefore, plays an efficient role as a 'filter' of suspended matter and nutrients coming from the upper watershed, thus protecting the receiving coastal zone from eutrophication. However, no water quality quantification and visualization has yet been made. Neither have strategic mitigation measures been proposed from the previous SR application in the lower RRD.

A large fraction of the total population of the Red River basin is settled in the delta area, espe- cially on the right bank where the Hanoi city and conurbation are located. This Day-Nhue River basin (DNRB) is one of the most polluted areas in northern Vietnam due to strong impacts of both point and non-point pollutant sources, e.g. wastewater from domestic, industrial, agricultural and aquacultural activities. At present, this river system is under considerable pressure from socio-economic development activities and urbanization, and the basin is experiencing an annual population increase of about $1.14 \%$ [15]. However, the region's infrastructure is incompatible with this rapid development [16]. The establishment and operation of industrial zones, including traditional handicraft villages, factories and agricultural areas, have caused significant changes to the delta environment. At the provincial level in Vietnam, towns and densely populated areas outside of large cities have poor sewage and septic systems. Together with domestic effluent, humanrelated socio-economic activities from such rural areas are significant pollution sources given their high population and poor infrastructure [16]. Traditional handicraft villages are examples of the sorts of trade activities that are common here, including rice noodle-making, weaving, ironmongery and so on [17].

We have chosen to apply the SR model on the Day-Nhue River basin in order to more fully understand the biogeochemical functioning of the delta system. Such an application allows us to assess the impact of point and diffuse pollutant sources from human activities (industries, agriculture) on water quality in a river basin undergoing rapid development. The outcomes from the model will identify nutrient sources and their respective contributions to the river basin, which is essential for policy makers to develop a general management framework for the aquatic environment. The first aim of this study is to develop a specific database for the application of the SR model in the DNRB. Although the SR has already been successfully applied to the Red River upstream, the complexity of downstream areas makes this more challenging. Our second aim is to assess the impact of human-related socioeconomic activities on the water quality.

\section{MATERIALS AND METHODS}

\section{Study site: the Day-Nhue River basin}

The Day-Nhue River basin (DNRB) extends over 5 provinces in northern Vietnam: Hoa Binh, Ha Noi, Ha Nam, Nam Dinh and Ninh Binh, covering from the latitude $20^{\circ} 00^{\prime} \mathrm{N}$ to $21^{\circ} 20^{\prime} \mathrm{N}$ and from the 
longitude $105^{\circ} 00^{\prime} \mathrm{E}$ to $106^{\circ} 30^{\prime} \mathrm{E}$. The Day River is one of the largest distributaries of the Red River. Its basin is rich in natural resources and plays an important economic role both nationally and as a part of the Red River Delta. The DNRB catchment area is about $7665 \mathrm{~km}^{2}$ covering a densely populated area with an estimated 10.3 million people in 2015. The average population density is over 1350 people per $\mathrm{km}^{2}, 5$ times higher than that of the national level [18]. The DNRB experiences the typical subtropical climate of Northern Vietnam, determined by monsoon regime: cold with little rain in winter, sunny and rainy in summer. Average annual rainfall for the entire delta is $1670 \mathrm{~mm}, 85 \%$ of which occurs from May to October (the rainy season) [19]. In general, there has been less rain in recent years, but it has occurred with higher intensity.

The river networks as well as the dam/dike and pumping station systems of the DNRB are described in detail in Luu et al [14] and Do et al [20]. The most striking characteristic of the Day-Nhue River system is the large contribution of the Red River to its total discharge primarily via the flow from 3 tributaries: Nhue River, Chau River and Dao River. These 3 tributaries are directly connected to the Red River and can supply up to $87 \%$ of the water discharged by the Day River water while the remaining $1 \%$ originates from the Day catchment area itself. However, Do et al [20] stated that water flow in the Chau River is negligible because it drains water to the Red River or Day River using a pumping station system to protect inner Hanoi from flooding during the rainy season. A dam was built at the conjunction of Chau River and Red River in 2008.

\section{The Seneque/Riverstrahler model and database preparation}

The aim of the deterministic SR model is to simulate the impact of human activities on the quality of river systems by describing the kinetics of all biogeochemical processes occurring within drainage networks. The drainage network of any river system may be considered as a combination of basins, idealized as a regular scheme of confluent tributaries of increasing stream order [21], each of which is characterized by mean morphologic properties and connected to branches represented with higher spatial resolution. The advantage of this representation of the drainage network is that the processes occurring in small firstorder streams headwater streams and large tributaries can all be taken into account.

The model couples water flows routed through the defined structures of basins and branches with

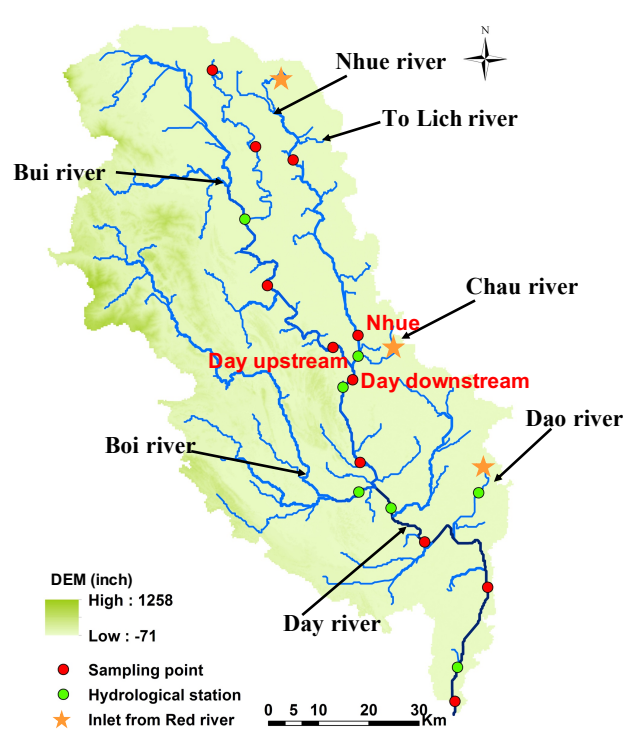

Fig. 1 Map of Day Nhue River basin and water quality and hydrological stations in this study.

a description of the biological, microbiological and physicochemical processes occurring within the water masses. The variables comprise nutrients, oxygen, suspended matters, dissolved and particulate non-living organic carbon as well as algal, bacterial, and zooplankton biomass. Most of the important processes in the transformation, elimination and/or immobilization of nutrients within the network of rivers and streams are explicitly calculated, including algal primary production, aerobic and anaerobic organic-matter degradation by planktonic and benthic bacteria, oxygen consumption and nutrient remineralization, nitrification and denitrification, phosphate reversible adsorption onto suspended matter and subsequent sedimentation. A detailed description of the model and of the parameters used can be found in Garnier et al $[22,23]$ and Thieu et al [2] and, for benthic processes, in Thouvenot et al [1].

\section{Geomorphology - the hydrographical network}

The whole GIS database is structured according to the representation of the drainage network as a system of connected directional arcs with each confluence marking the beginning of a new arc. Each arc is described by data such as Strahler stream order, length, width and slope, representing the area which drains directly to this arc. This constitutes the elementary spatial grid of the model. A reliable digital representation of the drainage network may be 
obtained by classical GIS-based treatments from the Digital Elevation Model (DEM) Shuttle Radar Topography Mission (SRTM) at 3 inch resolution that was made available at global scale by NASA (www. NASA.org) using method from Tarboton et al [24]. However, in the case of the Day and Nhue River system with low elevation, flat topography and a high drainage density, DEM-derived outputs can prove to be inaccurate. Thus, additional treatments based on drainage enforcement in the DEM are required $[25,26]$. The obtained representation is shown in Fig. 1.

\section{Hydro - meteorological data}

The SR model calculates the seasonal variations of discharge using specific base flow and superficial runoff by periods of 10 days for each subbasin. These results are used for reconstructing the discharge anywhere in the drainage network and calculating the diffuse sources of nutrients from the basin. For the case of DNRB, we obtained these specific discharges by using the recursive digital filter baseflow separation method [27] on observed daily discharges at 7 stations within the hydrological network (Fig. 1).

\section{Land use and non-point sources of nutrients}

To calculate diffuse sources of nutrients in each sub-basin, the SR model assigns a yearly constant mean composition to surface- and base-flow runoff, respectively, according to land use of the basin. A GIS land use coverage of the Vietnamese territory was made available from the Ministry of Natural Resources and Environment of Vietnam [28]. We considered the following 7 classes as the most relevant for our purpose: paddy field, forest, rock, grassland, shrub-land, urban area and agriculture [29]. Land use layers for 2 target years were thus created (Fig. S1a). For the DNRB, we relied on an extensive survey of literature and on our own measurements from the sampling sites shown in Fig. 1. For this study, the years 2006 and 2015 were chosen for model validation because they have similar meteorological and hydrological conditions and span a period of intense economic development.

\section{Point sources of nutrients}

\section{Domestic wastewater}

The basic information on domestic wastewater release is the population census by commune (or village) $[15,18]$, which can be georeferenced (Fig. S1b). The census is available for the period from 2006 to 2015 for 900 communes, including a distinction in terms of rural or urban population. With the human per capita food consumption data and their N, P and Si content, we estimated the yearly per capita nutrient load in the order of $5.6 \mathrm{~kg} /$ capita/year for $\mathrm{N}, 0.7 \mathrm{~kg} /$ capita/year for P and $0.04 \mathrm{~kg} /$ capita/year for $\mathrm{Si}$.

The assumption was made that the wastewater discharge is $80 \mathrm{l}$ /capita/day in 2006 and $100 \mathrm{l} /$ capita/day in 2015 [30]. Besides, on the basis of the Master Plan on environmental protection of NhueDay River basin toward 2020 approved by Prime Minister [31], it is assumed that all of the wastewater from urban areas is collected in a sewage system and is then delivered to rivers without treatment in 2006 , and $20 \%$ of wastewater was treated through purification stations in 2015 while in rural areas, only $50 \%$ of the domestic wastewater reaches surface waters, the rest being recycled into agricultural soil. Thus, policymakers could use SR model as a tool for assessing impacts of management options on quality of water environments.

\section{Industrial wastewater}

Due to the lack of a complete industrial wastewater database as required by the modeling approach, we have developed a procedure to gather the information on the representative enterprises within the RRD on their production, discharge and water quality variables such as $\mathrm{pH}$, suspended matters (SM), dissolved oxygen (DO), nutrients $\left(\mathrm{NO}_{3}, \mathrm{NO}_{2}\right.$, $\mathrm{NH}_{4}, \mathrm{~N}$ total, $\mathrm{PO}_{4}, \mathrm{P}$ total and $\mathrm{DSi}$ ). The questionnaire was constructed and sent to a number of enterprises whose addresses were sourced from the Ministry of Science and Technology and Environment of Vietnam [29]. The addresses were used to georeference the industries to the level of the smallest administrative unit (the commune) (Fig. S1c). To support the questionnaire data, we collected and analyzed samples taken from various industrial sectors around Hanoi. Therefore, we constructed a layer to provide information on industrial wastewater including suspended matters, organic matters, total nitrogen and total phosphorus release into the environment (in $\mathrm{kg}$ per day). Industrial nutrient discharge and quality are discussed in more detail in Luu et al [13], and industrial zones are considered as point sources.

\section{Water quality}

Water quality was monitored monthly in 2006 and 2015 as a preliminarily comparison for the SR model 
simulation results. In 2006, monthly sampling was only conducted at 3 stations, named Nhue, Day downstream and Day upstream for model validation; other sampling points were taken in April and August, which could be representative for dry and rainy season in Northern Vietnam. Sampling points were selected based on their strategic positions in the river network; for example, at the junction between the main channels or outflows of industrial and urbanized zones. Physico-chemical information (temperature, $\mathrm{pH}, \mathrm{DO}$ and conductivity) was obtained in situ with the use of a Hydrolab Sonde DS5 (USA). Each water sample was collected in a $1 \mathrm{~L}$ polyethylene bottle and stored at $4^{\circ} \mathrm{C}$ in an icebox during transport to the laboratory where subsamples of water were filtered through GF/F membrane filters (Whatman, $0.7 \mathrm{~m}$ pore size) and kept cool. Concentrations of SM, $\mathrm{NH}_{4}, \mathrm{NO}_{3}, \mathrm{NO}_{2}, \mathrm{~N}$ total, $\mathrm{P}$ total and DSi in water samples were determined according to standard methods [32].

\section{Model validation}

Since our model is based on a deterministic approach, where all parameters are set a priori without a calibration step, a major challenge was the comparison between the simulation results of biochemical water-quality variables and available observations. The coherence between observed data and calculated results (discharge and water quality) is an index of both the accuracy of our information on the constraints and of our representation of the processes.

$$
\text { Nash }=1-\frac{\sum\left(\mathrm{X}_{\mathrm{calc}}-\mathrm{X}_{\mathrm{obs}}\right)^{2}}{\sum\left(\overline{\mathrm{X}}_{\mathrm{obs}}-\mathrm{X}_{\mathrm{obs}}\right)^{2}},
$$

where $X_{o b s}$ represents all observed values of a variable at any station and any time, $X_{\text {calc }}$ represents the calculated value of the variable at the same station and the same time and $\bar{X}_{\text {obs }}$ is the mean value of the observed variables.

The Nash criterion thus indicates the performance of the model according to a scale ranging from $-\infty$ to 1 , where 1 is perfect [33]. Agreement between the simulation and measurements as assessed by the Nash criterion is variable among the different stations (Nhue station, Day upstream and downstream station), and the lower agreement is explained by the complex water quality composition of the study area.

\section{RESULTS AND DISCUSSION}

In order to adapt the resolution of the model to the availability of the validation data and to take into account the 3 main sources of water from the Red River (Nhue, Chau and Dao Rivers), a suitable spatial representation of the river systems was defined which involved 7 branches (Day, Boi, Bui, Dao, Chau, Nhue and To Lich) and 3 Red River inlets (Nhue, Chau and Dao) (Fig. 1).

\section{Seasonal and spatial water quality of the day - field observation results}

From our surveys in 2006 and 2015, DO concentrations clearly increase from upstream to downstream (Fig. 2a). This phenomenon can be explained by the large amount of domestic and industrial wastewater discharged directly into the upstream river, which is diluted downstream with increased discharge. During the rainy season, average oxygen concentrations were lower than those during dry season. This pattern was reversed for the concentration of SM which was generally higher in the wet season (Fig. 2b). This is as SM limits light for photosynthesis and algal growth is known to be a favorable site for heterotrophic bacteria which consume oxygen [34, 35]. Both DO and SM concentrations were extremely high in the estuary ( $>200 \mathrm{~km}$ downstream). During the dry season, the organic contaminants derived from domestic and industrial pollution are less diluted by upstream water discharge so that the upstream waters became occasionally anoxic.

Monitored $\mathrm{NH}_{4}$ concentrations ranged from 0.01 to $3.4 \mathrm{mg} / \mathrm{l}$ with some upstream sites (to Phu Ly station in Fig. 1), exceeding the Vietnam Standards on water quality QCVN08-MT:2015/BTNMT of $0.05 \mathrm{mg} / 1$ for domestic use (Fig. S2a). Nitrite concentrations followed a similar pattern (Fig. S2b). The similar concentration range of $\mathrm{NH}_{4}$ and $\mathrm{NO}_{2}$ has been reported by other authors recently $[20,34,36]$. Lower concentrations of these reduced $\mathrm{N}$ forms were generally found in the unpolluted Day River downstream, where $\mathrm{NH}_{4}$ is processed very quickly by microorganisms including autotrophic algae, heterotrophic bacteria, and autotrophic nitrifying bacteria. High $\mathrm{NH}_{4}$ concentrations typically signify domestic wastewater pollution $[20,36]$. In the upstream area with such high concentrations of $\mathrm{NH}_{4}$ and $\mathrm{NO}_{2}$, the surface water in the basin tends to be eutrophic and prone to phytoplankton blooms which color the waters green and turquoise. $\mathrm{NH}_{4}$ concentrations were generally higher in the dry than in the rainy season due to dilution effects by rainwater in both 2006 and 2015 . The difference between dry and rainy seasons is less distinct for $\mathrm{NO}_{2}$ concentrations.

Nitrate concentrations in river waters origi- 

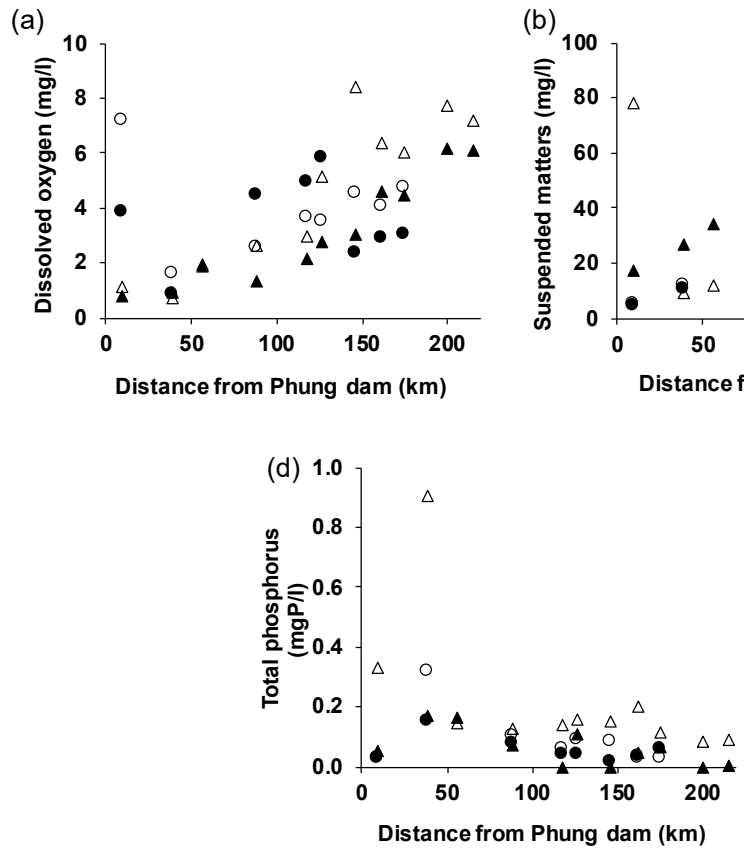
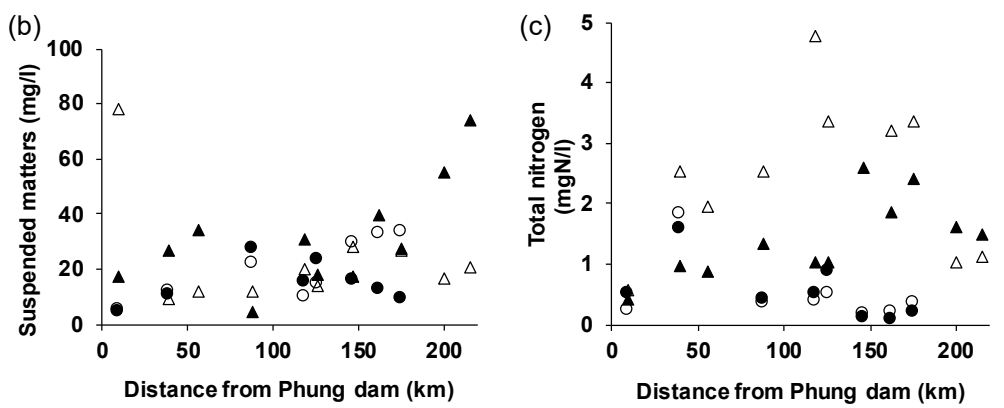

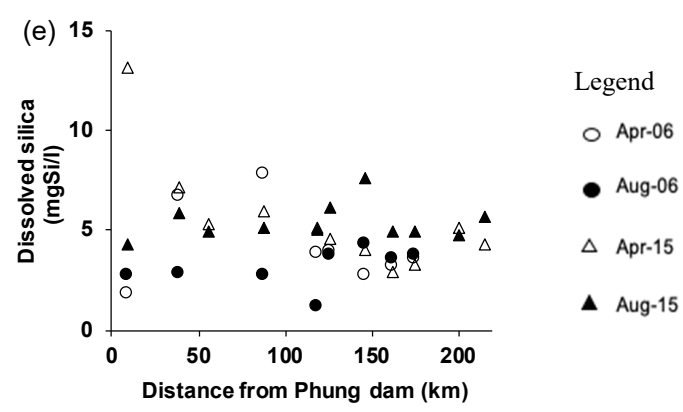

Fig. 2 Longitudinal variation of dissolved oxygen (a), suspended matters (b), total nitrogen (c), total phosphorous (d) and dissolved silica (e) concentrations in Day river in dry season (April) and rainy season (August) in 2006 and 2015.

nate mainly from agricultural runoff when a large proportion of the surface area is fertilized, but in river sectors impacted by domestic wastewater, a significant contribution may originate from the nitrification of $\mathrm{NH}_{4}$. This assumption has been demonstrated by novel stable isotope techniques presented in Luu et al [36]. In river catchments influenced by intensive agricultural activities, $\mathrm{NO}_{3}$ contamination usually correlates with the quantity of fertilizer used. In our river system, the highest $\mathrm{NO}_{3}$ content (Fig. S2c) was often found in the dry season, although anoxic conditions can lead to $\mathrm{NO}_{3}$ elimination by denitrification. $\mathrm{NO}_{3}$ content varied from 0.01 to $4.8 \mathrm{mgN} / 1$. The content of $\mathrm{NO}_{2}$ ranged from 0.001 to $1.82 \mathrm{mg} / \mathrm{l}$ compared to the Vietnam Standards on water quality of $0.01 \mathrm{mg} / \mathrm{l}$ for domestic use. $\mathrm{NO}_{2}$ concentrations (Fig. S2b) as low as $0.1 \mathrm{mgN} / 1$ may affect aquatic life including fish, and toxicity increases when $\mathrm{pH}$ and salinity decrease. Fig. $2 \mathrm{c}$ reveals that total nitrogen content in river water increased from upstream to downstream and was higher in the rainy season. As reported in Luu et al [36], this total $\mathrm{N}$ content was similarly increased in upstream compared to downstream reaches in the period between 2016-2018.

In freshwaters, phosphorus is often the main factor that limits the production of primary producer biomass. Phosphate can be dissolved or adsorbed to particles and becomes available by desorption. Phosphorus tends to be limited for phytoplankton in the range from 0.01 to $0.9 \mathrm{mgP}-\mathrm{PO}_{4} / 1$, which corresponds to the value of the half-saturation constant for phosphate uptake by algae. Similar to N, there was no clear seasonal or spatial variation of $\mathrm{P}$ content in river water (Fig. 2d). Phosphate content represents in general $40 \%$ of $\mathrm{P}$ total in natural river water.

Dissolved silica (DSi) in rivers mainly originates from rock weathering and therefore depends on the lithology. Higher DSi concentrations were found in the upstream river (Fig. 2e). This implies that the domestic and industrial waste (urban effluent) is a source for DSi for the Day River. Although DSi input from domestic waste is usually rather low, industrial effluents might also be a significant source of silica. The DSi content in the Day River was rather stable, showing that biological consumption of silica is low.

It is important to note that $\mathrm{NH}_{4}$ and $\mathrm{N}$ total concentrations in 2015 are all higher than the ones in 2006, indicating a decline in water quality of the river system between 2006 and 2015. Increases in domestic wastewater discharge from inner Hanoi to the river system and the greater application of chemical fertilizers in paddy field (about half of landuse 
in the river basin; Fig. S1a) are likely responsible for higher $\mathrm{N}$ loading.

The river loading of $\mathrm{N}$ total, $\mathrm{P}$ total and DSi at the outlet of the Day River was compared with the Redfield ratio in order to assess the balance of riverine nutrient delivery for biotic uptake. As the $\mathrm{P}$ total concentration was extremely low at that point leading to high ratio N/P $(\sim 27.5)$ compared to the Redfield ratio $(\mathrm{N} / \mathrm{P}=16)$ suggesting that $\mathrm{N}$ is the limiting nutrient for autotrophic growth. This observation is coherent with our previous results based on nutrient budgets in the Red River Delta [13].

\section{Seasonal variation at key stations - comparison} of simulated and measured outcomes

In this section, we compare the field observations with preliminary results estimated by the SR model, using the prepared GIS layer. Calculated seasonal variations in discharge, $\mathrm{SM}, \mathrm{DO}, \mathrm{NO}_{3}, \mathrm{NH}_{4}, \mathrm{P}$ total and DSi for 2006 and 2015 were compared with measurements obtained during the surveys in the same period at Nhue station on the Nhue River and at the Day upstream and downstream stations on Day River (Fig. S3). Nhue station represents wastewater discharge from inner Hanoi and mainly originates from households and small industries or craft villages. The Day upstream and Day downstream stations represent water quality of the Day River before and after receiving water from Nhue River.

Agreement between observed and calculated discharge was high in the Day upstream (Nash value is 0.92 ) and Day downstream (Nash value is 0.81) stations but was poor at Nhue station (Nash value is 0.25) (Fig. S3). That reflects the fact that pumping stations for agricultural purposes in the Nhue River basin [20] are not included in the SR model. The improved Nash criteria for the Day River, however, do not validate the model, but are explained by the fact that specific discharge data used by the model is calculated from the same observed discharge data; therefore, the match is an artifact that checks how correct the algorithms is.

The model performs quite well for SM with a Nash value of 0.78 . The model simulates the SM variability in the Nhue well because the operation of lock systems controls the Red River inputs. The model overestimates SM in the downstream Day in the rainy season, which could be explained by the huge contribution of Dao River to the downstream Day River, especially in the rainy season.

The model reproduced the general trends in DO content, but the simulation of the Nhue was very variable in response to the rather erratic Red River inputs. Similar variability in $\mathrm{NO}_{3}$ concentrations was simulated in the Nhue River, as periods of low DO are characterized by intense denitrification. Over the year, the model tends to overestimate nitrate levels.

The model overestimated $\mathrm{NH}_{4}$ and had a low performance for this variable. This is explained by the fact that the quality of the river water at Nhue station and Day upstream station receives domestic and industrial wastewater discharge, whereas the downstream river is heavily influenced by paddy fertilization [20]. P total contents were also overestimated by the model, which may be due to overestimation of the per capita release of domestic $\mathrm{P}$ which was set to $4 \mathrm{gP} /$ inhabitant/day. Silica trends are simulated quite well but are slightly overestimated in the Day River. In general, the DSi is stable during the year, showing no significant seasonal variations and indicating that no large biological consumption of silica occurs.

\section{Cartographic representation}

The Seneque interface of the SR model is an optimized tool for assessing the spatial distribution of overall water quality at the scale of the whole drainage network. Fig. 3 and Fig. S4 show snapshot images of the distribution of water quality variables over the entire Day watershed area during the dry season (using the year 2006 as an example). In the case of SM (Fig. 3), the maps show the major impact of the direct Red River inputs via the Nhue, Chau and Dao Rivers. Loadings from domestic and industrial activities are the major sources of $\mathrm{NH}_{4}$, and the tool implies high concentrations in both dry and rainy seasons (Fig. S4) in the areas where population density is highest (Fig. S2). P total which is also derived from point sources (domestic and industrial) has a similar spatial distribution to $\mathrm{NH}_{4}$, i.e. high concentrations in the urban areas (Fig. S1c). Thus, the SR model could quantify and visualize the spatial distribution of pollution in the target site, helping policymakers and local authorities at different governing levels to propose appropriate mitigation measures more easily.

\section{Calculated budget of nutrient transfer, retention and delivery}

One of the most useful capabilities of the SR model is to calculate a comprehensive budget of nutrient inputs, transformation and delivery for the whole river network [13]. The calculated retention indicated that the processes taken into account in the 

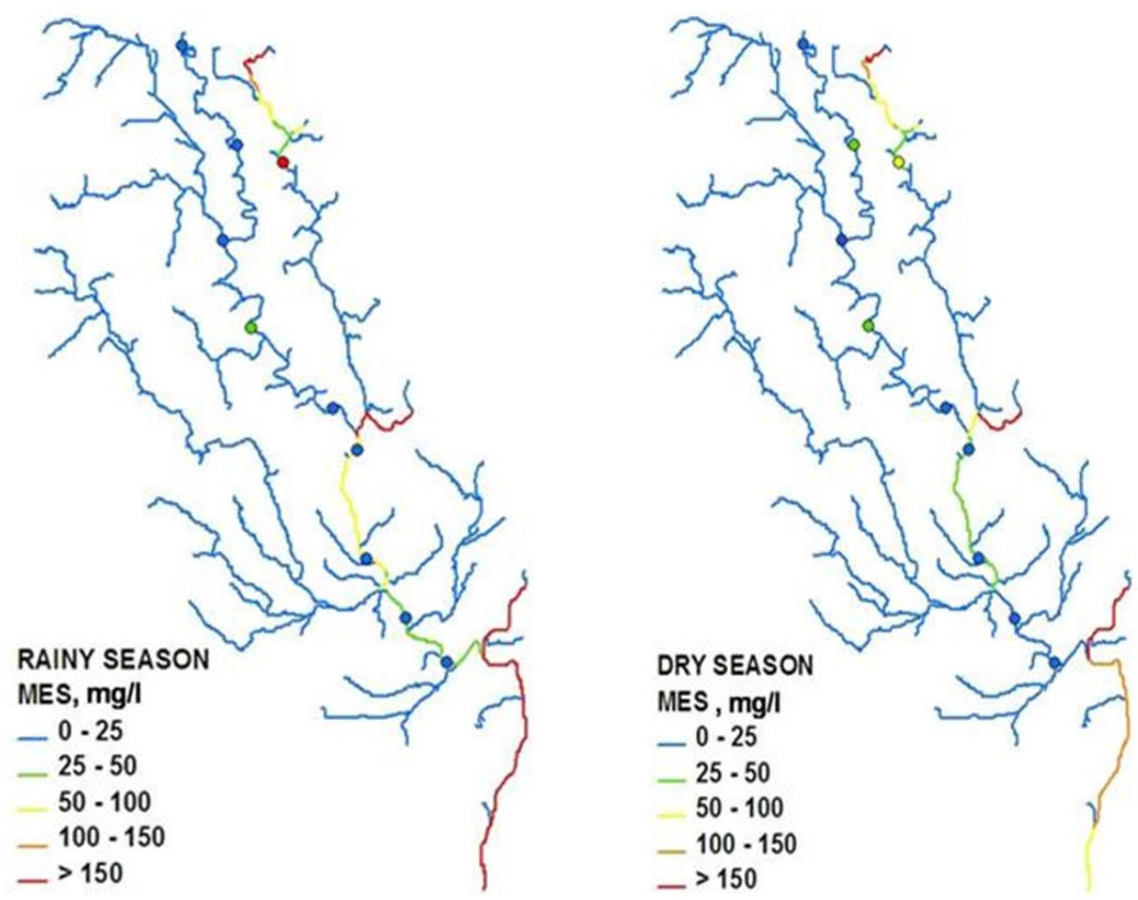

Fig. 3 Geographical distribution in dry season and rainy season of suspended matters over the drainage network in 2006 as calculated by Seneque/Riverstrahler model. Vietnam Standards (QCVN08-MT:2015/BTNMT) for suspended matters is $20 \mathrm{mg} / 1$ for domestic use.

SR model lead to retention in the DNRB, right bank river network of the Red River Delta of $80 \%$ of the incoming SM, $67 \%$ of $\mathrm{N}$ total, $47 \%$ of $\mathrm{P}$ total and $5 \%$ of DSi. These retention figures are quite consistent with those deduced from the empirical budgeting approach developed earlier [13], which are $86 \%$, $50 \%, 69 \%$ an $6 \%$ for SM, $\mathrm{N}$ total, $\mathrm{P}$ total and DSi retention, respectively.

\section{Exploration of water quality management measure}

The Nhue River and the portion of the Day River downstream of the Nhue confluence are clearly the most affected by anthropogenic pollution in the whole drainage network of the Day River (and probably also of the whole river basin). The operation of the lock systems allowing direct inputs of Red River water to the upper Nhue River offers an efficient way to control the water quality of these regions. Here, we make use of the Seneque model results to study how the diversion of Red River water is effective in controlling water quality along the longitudinal profile of the Nhue and the Day Rivers. Fig. S5 shows the relationship between Red River input (via Nhue and Chau Rivers) and oxygen concentration at 2 key points on the Nhue River during different seasons. They span a range of discharge and variable contributions of direct Red River inputs. At the upstream Nhue station, oxygen concentration increases rapidly with Red River inputs in both dry (specific discharge $<110 \mathrm{l} / \mathrm{s} / \mathrm{km}^{2}$ ) and rainy (specific discharge $>110 \mathrm{l} / \mathrm{s} / \mathrm{km}^{2}$ ) seasons. Oxygen is always replete when Red River discharge inputs to the Nhue River exceed $60-80 \mathrm{~m}^{3} / \mathrm{s}$. At the outlet of the Nhue river, water quality declines progressively due to the accumulation of domestic and industrial inputs along the river (Fig. S1). In the dry season, water coming from the Red River is the main contributor to the Nhue River discharge, so that a strong positive relationship is found between water quality (oxygen concentration) and the amount of Red River water diverted. In the wet season, the discharge from the Nhue watershed itself is high enough to prevent oxygen depletion (and denitrification - Fig. S3).

This analysis clearly shows that the openingclosure schedule of the gates along the Nhue River plays a substantial role in regulating water quality of the Nhue River and could be used as a way of preventing oxygen depletion (and also denitrification) 
in the Nhue River. This is a substantive finding on river management and water pollution control in the Nhue River for the city of Hanoi and can, therefore, better improve the quality of the Red River and its downstream delta.

\section{CONCLUSION}

The work presented in this study shows the effectiveness of the SR model for describing the ecological functioning of river systems in Day-Nhue River basin. The model allows a description of the variability in water quality at the scale of the entire drainage network, downstream of the Red River Basin. In this first application of the model in the DNRB, we focus on preparing databases for the SR calibration. DEM data was successfully created by mapping pretreatment using ArcGIS. An industrial wastewater distribution layer has been developed from questionnaire surveys, and water quality monitoring for the year 2006 and 2015 was used to check the quality of the inner equations in the model. In the case of the Day-Nhue River basin, the model has succeeded in simulating the major trends of mean temporal and spatial variations. The calculated budgets of N, P and Si are consistent with those calculated empirically, suggesting the extremely efficient retention of suspended matters, $\mathrm{N}$ and $\mathrm{P}$ delivered to the delta area from the upstream Red River catchment can indeed be explained by the biogeochemical processes accounted for the model of the Day and Nhue River system. Model adaptation to improve the agreement between the observation and model simulation is currently in progress so as to better inform of more effective river management.

\section{Appendix A. Supplementary data}

Supplementary data associated with this article can be found at http://dx.doi.org/10.2306/ scienceasia1513-1874.2021.014.

Acknowledgements: This research is funded by Vietnam National Foundation for Science and Technology Development (NAFOSTED) under grant number NE/P014577/1 and 105.08-2014.26. We acknowledge the funding received from UKRI GCRF Living Delta Hub under Grant Reference NE/S008926/1. The authors would like to thank Dr. Josette Garnier and Dr. Gilles Billen (CNRS, France) for their supervision. Special thank is sent to Prof. Suzanne McGowan and Dr. Virginia Natalie Panizzo, School of Geography, Nottingham University, UK, for helpful advice and editing content of the paper.

\section{REFERENCES}

1. Thouvenot M, Billen G, Garnier J (2007) Modelling nutrient exchange at the sediment-water interface of River Systems. J Hydrol 341, 55-78.

2. Thieu V, Billen G, Garnier J (2009) Nutrient transfer in three contrasting NW European watersheds: The Seine, Somme, and Scheldt Rivers. A comparative application of the Seneque/Riverstrahler model. Water Res 43, 1740-1754.

3. Seitzinger SP, Mayorga E, Bouwman AF, Kroeze C, Beusen AHW, Billen G, Van Drecht G, Dumont E, et al (2010) Global river nutrient export: A scenario analysis of past and future trends. Global Biogeochem Cycles 24, ID GB0A08

4. Yua Y, Sun X, Zou L, Zhang H, Liu Y, Liu M (2020) Polycyclic aromatic hydrocarbons (PAHs) in surface soil from the Guan River Estuary in China: Contamination, source apportionment and health-risk assessment. ScienceAsia 46, 80-86.

5. Doan QT, Chen YC, Mishra PK (2013) Numerical modeling in water quality management for rivers: case study of the Day/Nhue river sub-basin, Vietnam. Int $J$ Earth Sci Eng 6, 1111-1119.

6. Bicknell BR, Imhoff JC, Kittle JL, Donigian AS, Johanson RC (1997) Hydrological Simulation ProgramFortran: User's Manual for Version 11, US Environmental Protection Agency, National Exposure Research Laboratory, Athens, GA.

7. Wade AJ, Durand P, Beaujouan V, Wessel WW, Raat KJ, Whitehead PG, Butterfield D, Rankinen K, et al (2002) A nitrogen model for European catchments: INCA, new model structure and equations. Hydrol Earth Syst Sci 6, 559-582.

8. Andersson L, Rosberg J, Pers BC, Olsson J, Arheimer B (2005) Estimating catchment nutrient flow with the HBVNP model: sensitivity to input data. Ambio 34, 521- 532 .

9. Lancelot C, Gypens N, Billen G, Garnier J, Robeix V (2007) Testing an integrated river-ocean mathematical tool for linking marine eutrophication to land use: the Phaeocystis-dominated Belgian coastal zone (Southern North Sea) over the past 50 years. J Mar Syst 64, 218-228.

10. Le TPQ, Billen G, Garnier J, Théry S, Ruelland D, Nghiem XA, Chau VM (2010) Nutrient (N, P, Si) transfers in the subtropical Red River system (China and Vietnam): Modelling and budget of nutrient sources and sinks. J Asian Earth Sci 37, 9-274.

11. Le TPQ, Billen G, Garnier J, Chau VM (2015) Longterm biogeochemical functioning of the Red River (Vietnam): past and present situations. Reg Environ Change 15, 329-339.

12. Causse J (2011) Étude et modélisation de la contamination fécale dans le réseau hydrographique de la Nam Khan (Nord Laos), Master thesis, Univ Pierre et Marie Curie, Paris. 
13. Luu TNM, Garnier J, Billen G, Le TPQ, Némery J, Orange D, Le LA (2012) N, P, Si budgets for the Red River Delta (Northern Vietnam): How the delta affects river nutrient deliveries to the sea. Biogeochemistry 107, 241-259.

14. Luu TNM, Garnier J, Billen G, Le TPQ, Némery J, Orange D, Tran HT, Le LA (2010) Hydrological regime and water budget of the Red River Delta (Northern Vietnam). J Asian Earth Sci 37, 219-228.

15. GSO (2020) Vietnam Population and Housing Census 2019, General Statistical Office, Vietnam.

16. MOC (2009) Monitoring, Planning and Managing Solid Wastes in Provinces of Day-Nhue River Basin Toward Year 2020, Ministry of Construction, Vietnam. [in Vietnamese]

17. Dang KC (2005) Vietnam Craft Villages and Environment, Science and Technology Press, Hanoi, Vietnam. [in Vietnamese]

18. GSO (2016) Vietnam Population and Housing Census 2015, General Statistical Office, Vietnam.

19. IMHE (1996-2015) Annual Report on Hydrological Observation in Vietnam, Institute of Meteorology, Hydrology and Environment, Vietnamese Ministry of Environment and Natural Resources, Vietnam. [in Vietnamese]

20. Do TN, Tran VB, Trinh AD, Nishida K (2019) Quantification of nitrogen load in a regulated river system in Vietnam by material flow analysis. $J$ Mater Cycles Waste Manag 21, 974-983.

21. Strahler AH (1957) Quantitative analysis of watershed geomorphology. Eos Trans AGU 38, 1290-1299.

22. Garnier J, Billen G, Coste M (1995) Seasonal succession of diatoms and chlorophyecae in the drainage network of the River Seine: Observations and modelling. Limnol Oceanogr 40, 750-765.

23. Garnier J, Billen G, Hannon E, Fonbonne S, Videnina Y, Soulie M (2002) Modeling transfer and retention of nutrients in the drainage network of the Danube River. Estuar Coast Shelf Sci 54, 285-308.

24. Tarboton DG, Bras RL, Rodriguez-Iturbe I (1991) On the extraction of channel networks from digital elevation data. Hydrol Process 5, 81-100.

25. Saunders W (2000) Preparation of DEMs for Use in Environmental Modeling Analysis, Hydrologic and Hydraulic Modeling Support with Geographic Informa- tion Systems, ESRI Press, Redlands, CA.

26. Hutchinson MF (1989) A new procedure for gridding elevation and streamline data with automatic removal of spurious pits. J Hydrol 106, 211-232.

27. Eckhardt K (2008) A comparison of baseflow indices, which were calculated with seven different baseflow separation methods. J Hydrol 352, 168-173.

28. MONRE (2007-2016) Natural ResourcesEnvironment and Maps of Vietnam (NARENCA), Vietnamese Ministry of Natural Resources and Environment, Vietnam.

29. MOSTE (1997) Vietnamese General Statistics Officer, Ministry of Science, Technology and Environment of Vietnam, General Statistics Editor, Hanoi, Vietnam.

30. Do-Thu N, Morel A, Nguyen-Viet H, Pham-Duc P, Nishida K, Kootattep T (2011) Assessing nutrient fluxes in a Vietnamese rural area despite limited and highly uncertain data. Resour Conserv Recycl 55, 849-856.

31. TTCP (2014) Decision of the Prime Minister on August 18, 2014 Promulgating the Plan to Implement the Master Plan on Environmental Protection of Nhue-Day River Basin toward 2020, Government of Vietnam, Vietnam. [in Vietnamese]

32. Rice EW, Baird RB, Eaton AD, Clesceri LS (2012) Standard Methods for the Examination of Water and Wastewater, APHA, Washington, DC, USA.

33. Nash JE, Sutcliffe JV (1970) River flow forecasting through conceptual models. Part I: a discussion of principles. $J$ Hydrol 10, 282-290.

34. Duong TT, Nguyen HY, Le TPQ, Nguyen TK, Tran TTH, Le ND, Dang DK, Vu TN et al (2019) Transitions in diatom assemblages and pigments through dry and wet season conditions in the Red River, Hanoi (Vietnam). Plant Ecol 52, 163-177.

35. Duc TA, Marie PB, Georges V, Chau VM, Nicolas P, Loi VD, Le LA (2006) Biogeochemical modeling of the Nhue River (Hanoi, Vietnam): practical identifiability analysis and parameters estimation. Ecol Modell 193, 182-204.

36. Luu TMN, Do TN, Ioannis M, Virginia NP, Trinh AD (2020) Stable isotopes as an effective tool for N nutrient source identification in a heavily urbanized and agriculturally intensive tropical lowland basin. Biogeochemistry 149, 17-35. 


\section{Appendix A. Supplementary data}

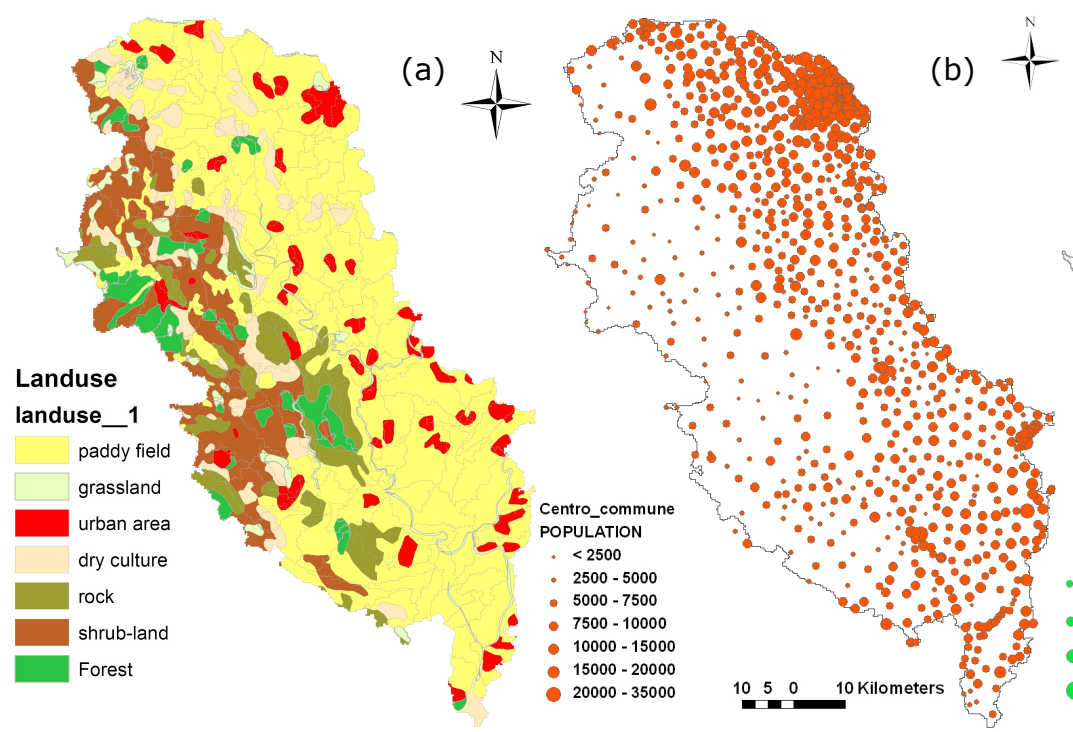

(c)

Fig. S1 Land use of the Day River basin (a), location of urban releases (b) and main industrial areas (c) in Day River basin.
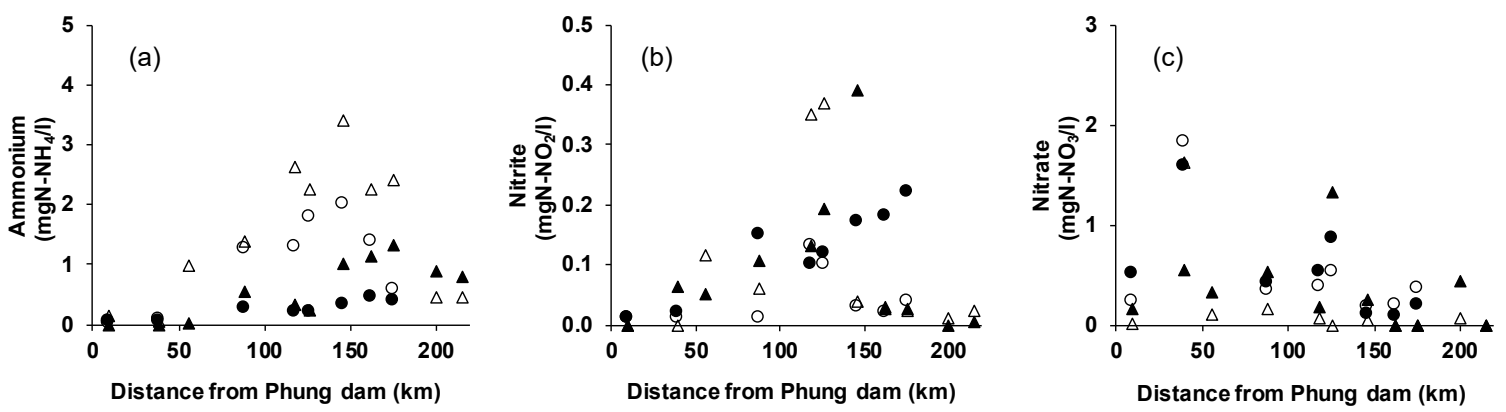

Fig. S2 Longitudinal variation of nutrient ammonium (a), nitrite (b), nitrate (c) concentrations in Day river in dry season (April) and rainy season (August) in 2006 and 2015. 
Nhue station
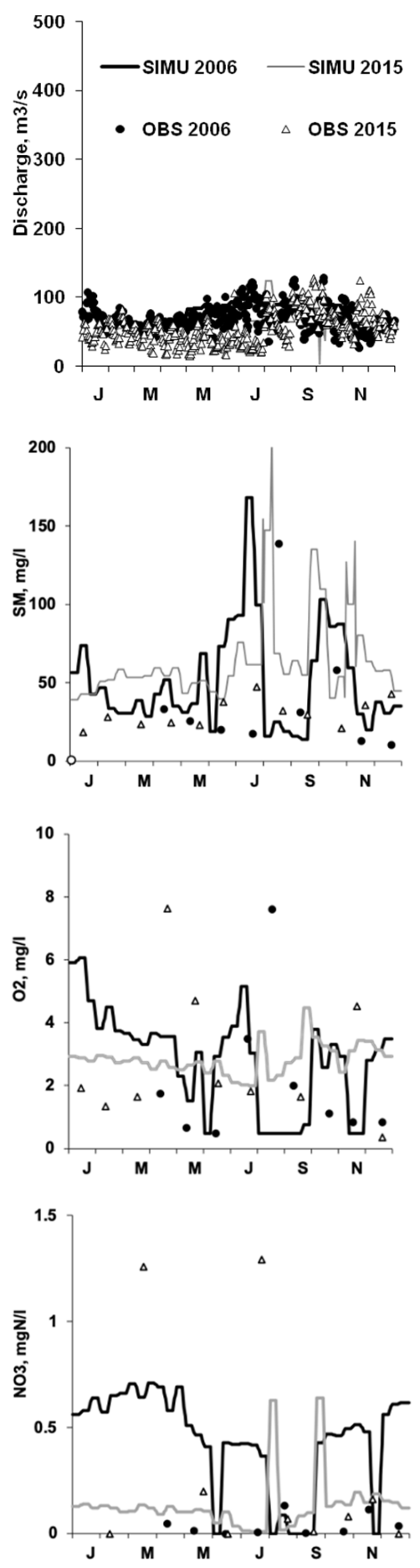

Day upstream station
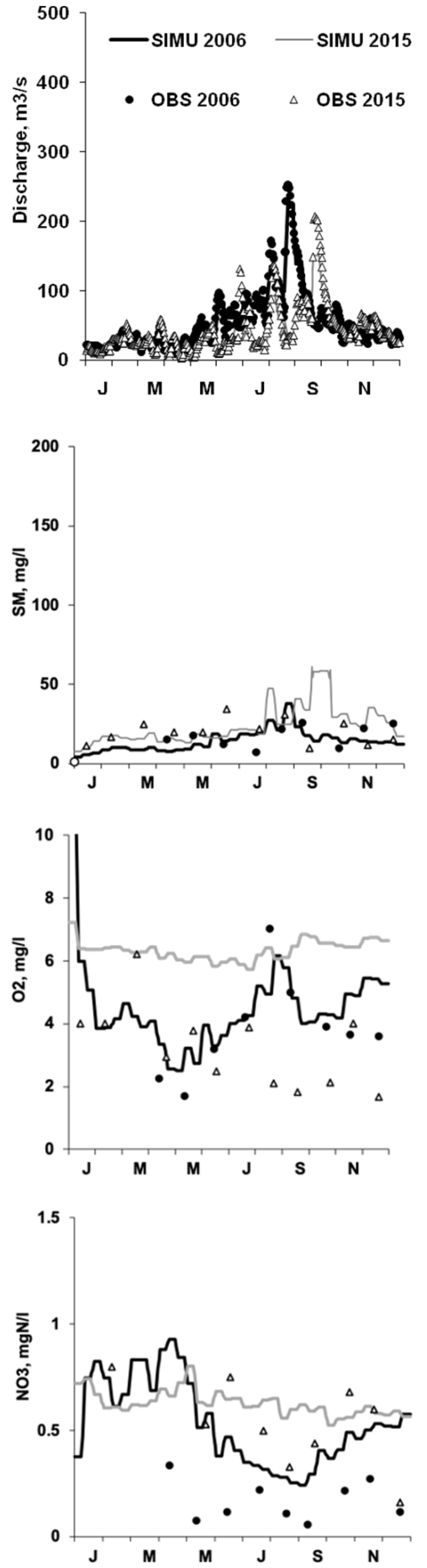

Day downstream station
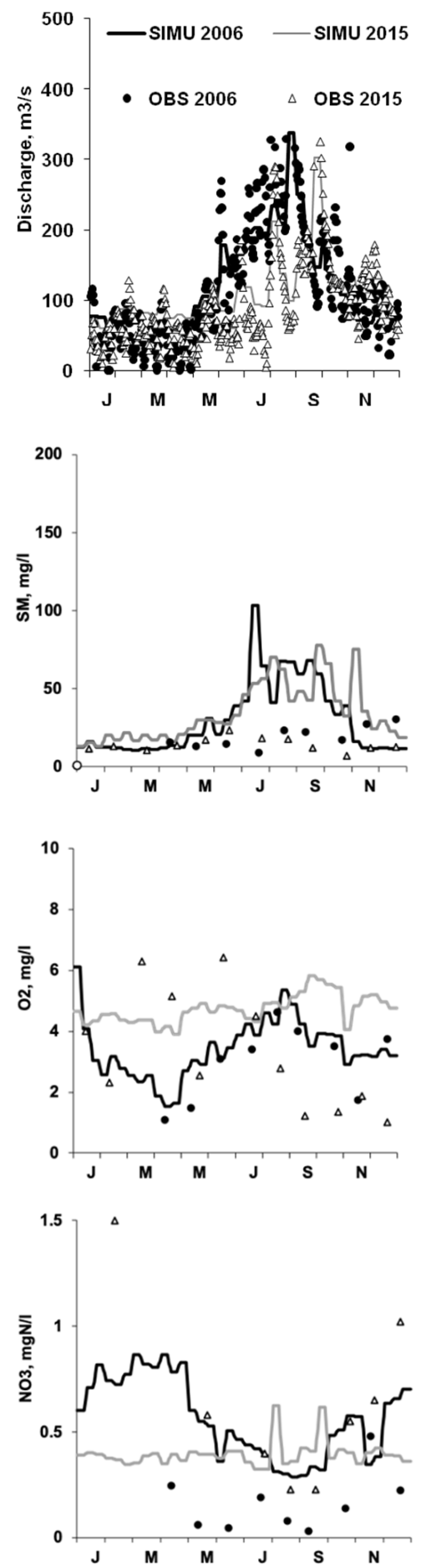

Fig. S3 Observed and calculated seasonal variations of nitrate, ammonium, total phosphorus and dissolved silica at Nhue station, Day upstream station and Day downstream station in 2006 and 2015. 


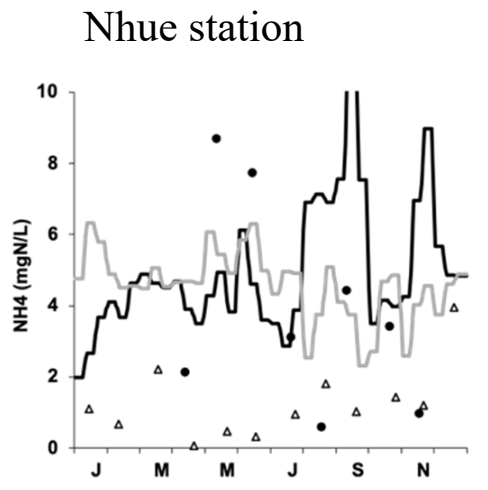

Day upstream station

Day downstream station
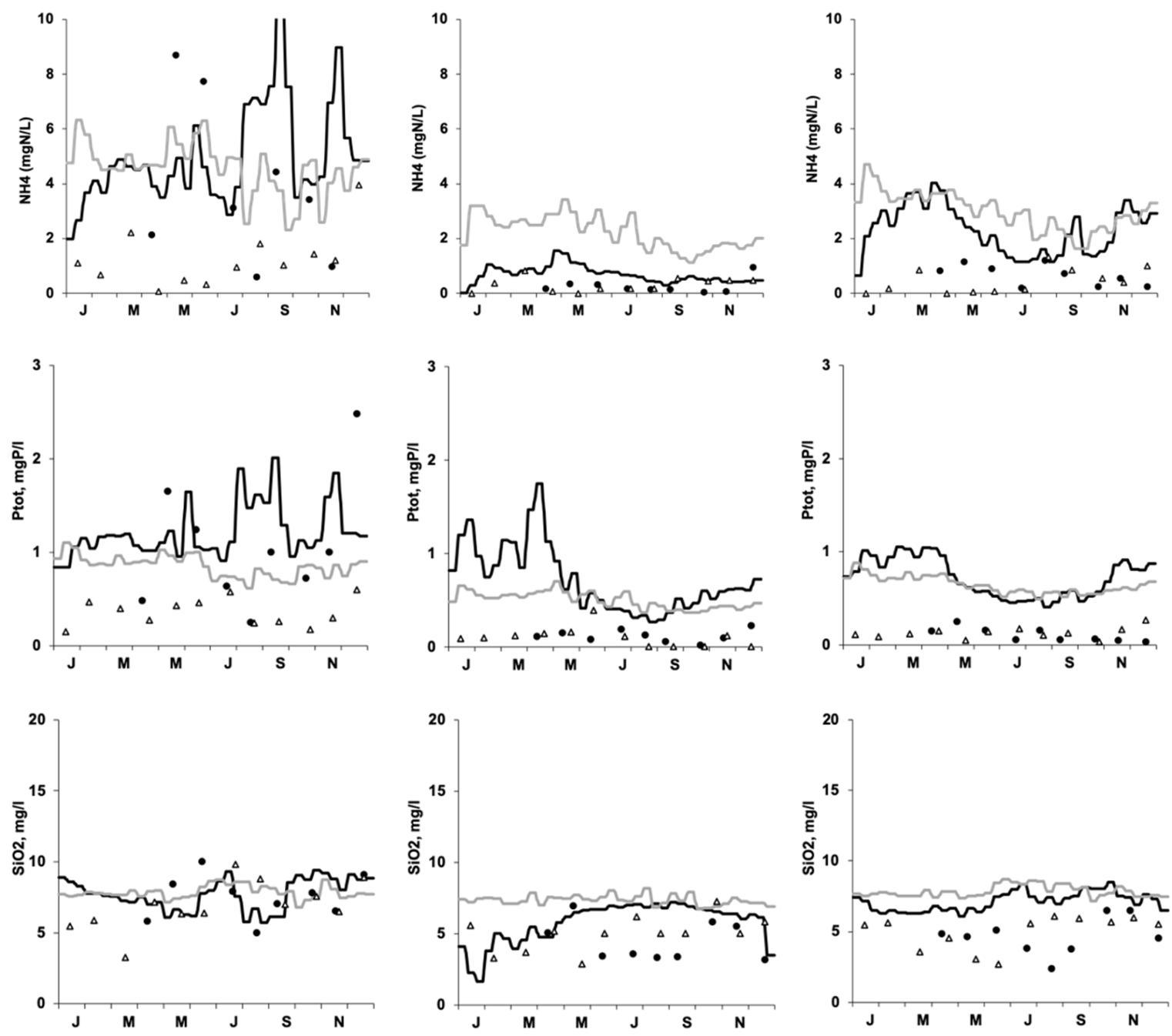

Fig. S3 Continued ... 

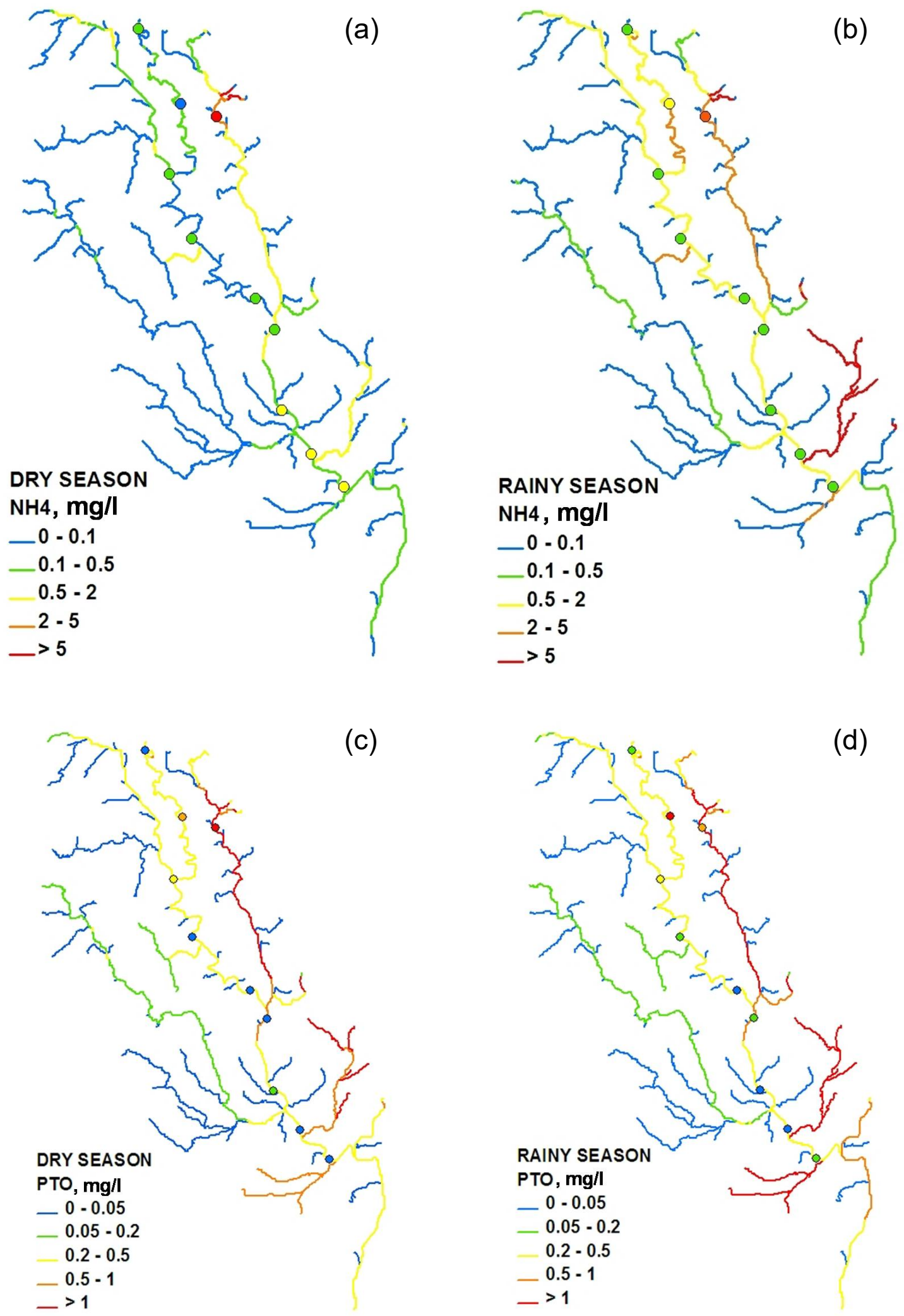

Fig. S4 Geographical distribution in dry season and rainy season of ammonium concentrations (a, b) and total phosphorus concentrations (c, d) over the drainage network in 2006 as calculated by Seneque/Riverstrahler model. 

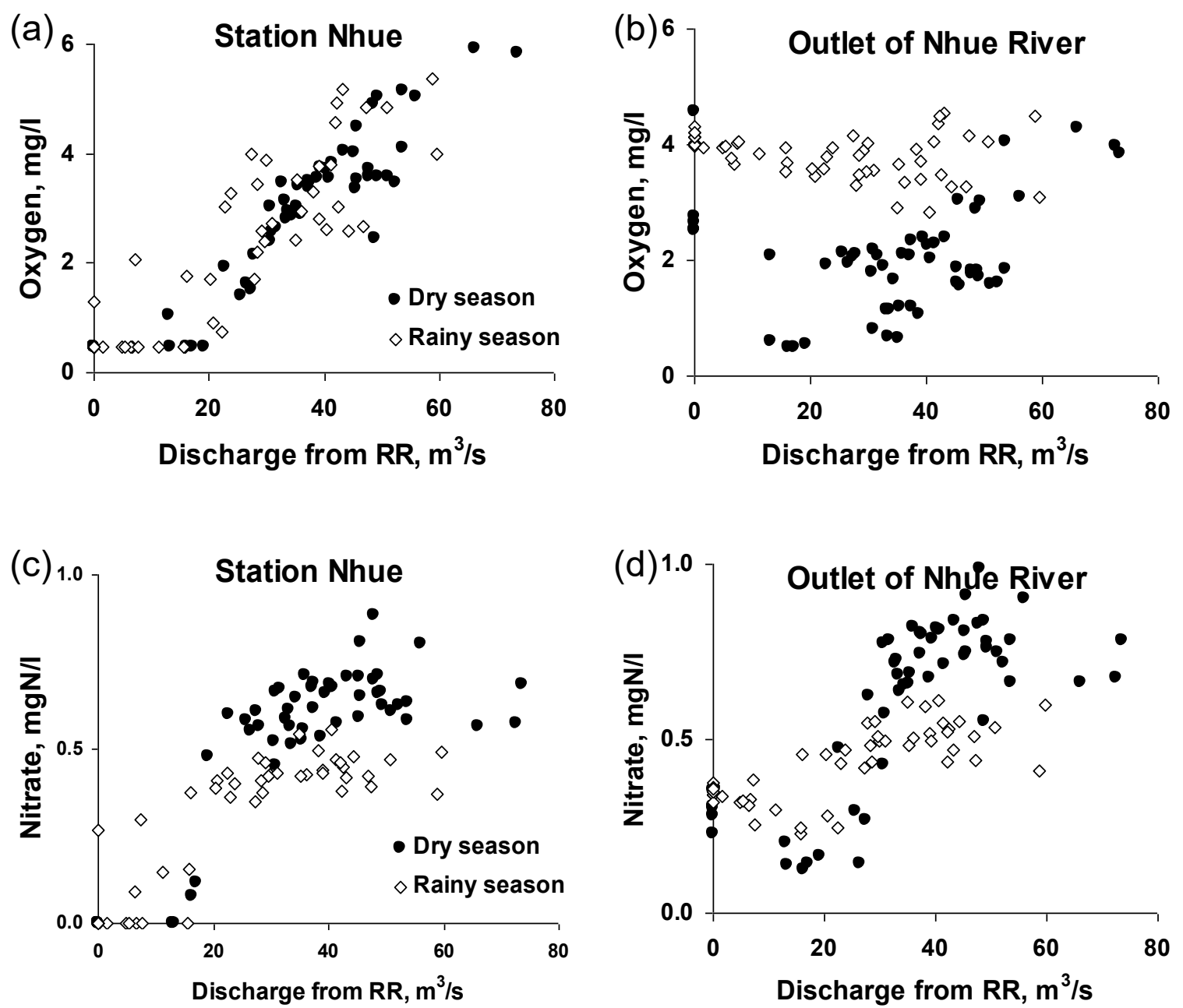

Fig. S5 Relationship between discharge from the Red River and Oxygen/Nitrate concentration at station Nhue (upstream of the Nhue River) (a, c) and at the outlet of the Nhue River before discharging to the Day River (b, d). 